\title{
Turystyka pielgrzymkowa zrównoważona - Karta sanktuarium dostępnego (Ksd)
}

\author{
Karolina Gołębieska ${ }^{*}$, Anna Ostrowska-Tryzno, Anna Pawlikowska-Piechotka \\ Katedra Turystyki, WTIR AWF Warszawa \\ * karolina.golebieska@awf.edu.pl
}

\section{Streszczenie}

Poznanie społecznych i przestrzennych uwarunkowań zrównoważonego rozwoju turystyki kulturowo - religijnej wydaje się problemem ważnym, ponieważ zainteresowanie tą formą w Polsce nie słabnie. Wśród nich jest wiele osób z niepełnosprawnością, starszych, rodzin z małymi dziećmi. Problematyka dostępności sanktuariów dla niepełnosprawnych nie była dotąd materiałem szerszych i pogłębionych studiów naukowych w Polsce, co zachęca do podjęcia rozważań nad tą problematyką. Szczegółowa analiza problemu możliwości znoszenia barier dostępności sanktuariów wydawała się autorom szczególnie istotna w kontekście spodziewanego ruchu pielgrzymkowego w Polsce w roku 2016 z okazji Światowych Dni Młodzieży. Jednym z założonych i osiągniętych efektów aplikacyjnych dorobku badań jest opracowanie 'Karty Sanktuarium Dostępnego'(KSD), pomocnego przy ocenie dostępności miejsc kultu religijnego dla osób z różnego rodzaju niepełnosprawnością. W przedstawionym tekście zaprezentowano dorobek badań ds.-144 oraz ds.-245 AWF Warszawa (granty Ministerstwa Nauki i Szkolnictwa Wyższego na lata 2014 - 2018).

\section{Słowa kluczowe}

turystyka religijna, sanktuaria Warszawy i Regionu Mazowsza, niepełnosprawność, dostępność funkcjonalna świątyń

\section{Wprowadzenie}

Naczelną cechą turystyki zrównoważonej jest poszanowanie otoczenia i harmonijny rozwój w kontekście środowiska przyrodniczego, kulturowego i społecznego. Do tego ostatniego segmentu należy zasada powszechności uczestniczenia w różnych formach turystyki, osób niepełnosprawnych jako egzemplifikacja inkluzyjności społecznej (Grabowski 2007: 5-6, Inskeep 2001: 3-9, Łobożewicz 200o: 3-11, Skalska 2004: 6-11) . W naszym społeczeństwie jest to już znacząca grupa osób, a co więcej wraz z prognozowanymi zmianami demograficznymi - najprawdopodobniej w najbliższych dekadach będzie stale rosnąć (GUS 2016: 41-90).

Likwidowanie barier architektonicznych i urbanistycznych, w tym dostosowanie przestrzeni publicznej do potrzeb osób niepełnosprawnych jest nie tylko formalnym prawem, szlachetną obligacją etyczną, ale przede wszystkim racjonalną polityką społeczną, której celem jest przede wszystkim poprawa jakości życia i zwiększenie mobilności osób ze specjalnymi potrzebami 
(Łobożewicz 2000: 5-11; Morgulec et al. 2015: 47).

Do takiej strategii obligują nas zarówno rekomendacje EU jak i rezolucje ONZ, nie tylko ogólnie mówiące o konieczności znoszenia barier przestrzennych jak na przykład UN Convention on the Rights of Persons with Disabilities z roku 2006, ale także ukierunkowane w szczególności na turystykę osób z niepełnosprawnością, jak na przykład $U N$ Recommendations on Accessible Tourism for All z roku 2005. W wymienionych dokumentach szczególnie podkreślana jest waga udostępnienia szeroko rozumianej przestrzeni turystycznej (infrastruktury i usług) dla osób z dysfunkcjami ruchu, wzroku lub słuchu. Przepisy polskiego prawa są kompatybilne z tymi dokumentami, między innymi Ustawa Prawo Budowlane i towarzyszące jej rozporządzenia wykonawcze, w tym zawierające szczegółowe wskazówki Rozporządzenie Ministra Infrastruktury z roku 2002.

Tematem podjętych prac badawczych w ramach dwóch projektów statutowych: ds.-144 oraz ds.-245, obu realizowanych na Akademii Wychowania Fizycznego w Warszawie, było diagnoza przyczyn utrudnień jakie napotykają w miejscach kultu religijnego turyści - pielgrzymi z różnymi rodzajami niepełnosprawności oraz poszukiwania rozwiązań praktycznych umożliwiające ich przezwyciężenie. Jednym z założonych i osiągniętych efektów aplikacyjnych dorobku badań jest opracowanie 'Karty Sanktuarium Dostępnego'(KSD), pomocnego przy ocenie dostępności miejsc kultu religijnego dla osób z różnego rodzaju niepełnosprawnością.

\section{Turystyka religijna osób z niepełnosprawnością}

Zgodnie z danymi Zakładu Geografii Religii Uniwersytetu Jagiellońskiego oraz Katolickiej Agencji Informacyjnej co roku średnio $7 \mathrm{mln}$ Polaków (15\% ludności) bierze udział w pielgrzymce do miejsca kultu religijnego. Tym samym polscy pielgrzymi stanowią około 5\% wszystkich chrześcijan pielgrzymujących na świecie, w tym stanowią szacunkowo $20 \%$ pielgrzymów w Europie (Web-o1).

W Polsce znajduje się około 500 sanktuariów, w większości związanych z kultem maryjnym (430 sanktuariów maryjnych), a największe z nich, Jasna Góra, Łagiewniki, Licheń, Kalwaria Zebrzydowska czy Niepokalanów - są odwiedzane przez miliony wiernych w skali roku, w tym także przez przybyszów z zagranicy.

Rozkład przestrzenny sanktuariów w Polsce nie jest jednolity. W kilku regionach występuje wyraźna ich koncentracja (południe Polski), tylko w Karpatach jest ponad 130 sanktuariów i ośrodków pielgrzymkowych, co stanowi blisko 30\% ogółu miejsc kultu religijnego w Polsce [Fig. 1].

Zgodnie z najnowszymi opublikowanymi danymi Instytutu Statystyki Kościoła Katolickiego Pallotynów w Polsce, pielgrzymowanie jest niezmiennie fenomenem polskiej religijności, ilość osób pielgrzymujących stale rośnie (Web-o2). W naszym kraju pielgrzymują wszystkie pokolenia oraz grupy społeczne i zawodowe, w tym osoby $z$ różnego rodzaju niepełnosprawnością. Obserwowane są także stałe zmiany w charakterze pielgrzymek, najbardziej znaczące w odniesieniu do sposobu podróżowania, wieku, stałego miejsca zamieszkania oraz posiadanego wykształcenia jej uczestników (Web-o1):

- zmniejszyła się, w porównaniu do końca XX wieku, przewaga ludności wiejskiej, zwiększa się udział osób młodszych i wykształconych; zgodnie $\mathrm{z}$ danymi Instytutu w pielgrzymkach uczestniczy $22 \%$ mieszkańców wsi, $24 \% \mathrm{z}$ małych miast, $16 \% \mathrm{z}$ miast średnich i $15 \%$ z miast dużych.

- zwiększa się ilość lepiej wykształconych osób; do udziału w pielgrzymkach przyznaje się obecnie 20\% osób z wykształceniem podstawowym, $17 \%$ z wykształceniem zawodowym, 20\% z wykształceniem średnim i $18 \%$ z wykształceniem wyższym.

- $\quad$ stale rośnie ilość młodych pielgrzymów, o ile w końcu XX wieku wśród polskich pielgrzymów widoczna 


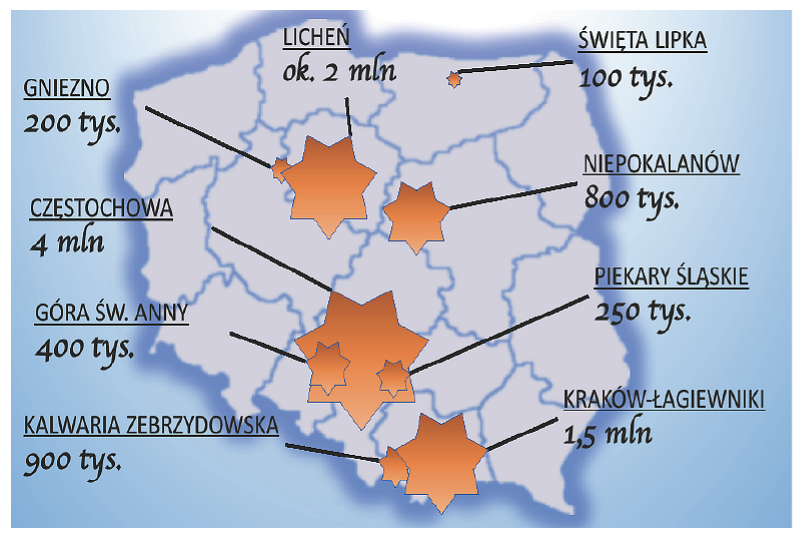

Fig. 1 Rozkład przestrzenny miejsc kultu w Polsce i szacunkowa liczba odwiedzających

Źródło: opracowanie Karolina Gołębieska na podstawie Instytut Statystyki Kościoła Katolickiego Pallotynów, marzec 2017 (ds.-144 oraz ds. 245 Akademia Wychowania Fizycznego Józefa Piłsudskiego w Warszawie, granty Ministerstwa Nauki i Szkolnictwa Wyższego)

była wyraźna przewaga osób starszych, wynosząca nawet $70 \%-80 \%$, to obecnie obserwuje się zwiększenie liczby młodych osób jako uczestników pielgrzymek; młodzież stanowi obecnie niemal połowę uczestników ogółu pielgrzymek, w tym zdecydowaną większość w pielgrzymkach w pieszych.

- rośnie ilość uczestniczących w pielgrzymkach młodych rodzin z małymi dziećmi (w wieku o-4)

- $\quad$ współcześni pielgrzymi podróżują w Polsce pieszo, autokarem, samochodem, rowerem - nawet na rolkach; jednak coraz mniejszy procent pielgrzymuje pieszo, a z roku na rok znacznie więcej osób przyjeżdża do sanktuariów samochodem lub autokarem; pojawiają się też nowe, dawniej nie praktykowane, sposoby pielgrzymowania, na przykład pielgrzymki piesze są uzupełniane o 'maratony', odcinki tras pokonywane biegiem.

W tym kontekście zrozumiałym staje się fakt, że władze terytorialne powinny element ruchu pielgrzymkowego uwzględniać w strategiach rozwoju. Na przykład Kraków jest jednym z miast, które w swojej strategii zrównoważonego rozwoju uwzględniły turystykę religijną (w tym osób z różnego rodzaju niepełnosprawnością), jako istotny czynnik, który należy rozważyć. W Strategia Rozwoju Turystyki w Krakowie na lata 20o6-2013 uchwalonej w 2006 roku podkreślono szczególne znaczenie Sanktuarium Bożego w Łagiewnikach oraz klasztoru w Tyńcu (Kapera 2011: 271-282).

Instytut Statystyki Kościoła Katolickiego Pallotynów nie dysponuje obecnie miarodajnymi danymi odnośnie procentowej ilości osób z niepełnosprawnością wśród uczestników pielgrzymek do miejsc kultu religijnego w Polsce. Natomiast na podstawie prowadzonych obserwacji przez organizatorów wyjazdów oraz administrację sanktuariów wiadomo, że liczba takich osób stale rośnie, ponieważ pojawią się coraz dalej idące ułatwienia w czasie podróży oraz na miejscu, w odwiedzanym sanktuarium. Wśród beneficjentów tych zmian są na przykład użytkownicy wózków, osoby niewidome lub niedowidzące, osoby starsze i opiekunowie z małych dzieci. ${ }^{1}$

Wyjazdy zagraniczne pielgrzymów polskich z niepełnosprawnością, do tak

$1 \mathrm{Na}$ podstawie: materiały prasowe Katolickiej Agencji Informacyjnej, marzec 2017 (www. opoka.pl) 
popularnych i znanych miejsc kultu religijnego jak Rzym, Lourdes czy Fatima nie mają na ogół większych ograniczeń - ponieważ współczesna podróż, szczególnie samolotem, oraz wymienione sanktuaria i ich otoczenie są w pełni przygotowane (poza sytuacją szczególną) dla osób wymagających znoszenia barier, na przykład pielgrzymów z dysfunkcjami ruchu lub wzroku.

Z tego też powodu w ciągu ostatniej dekady rośnie ilość wyjazdów do sanktuariów zagranicą osób starszych oraz młodych rodzin z małymi dziećmi (w wieku o-4).

Ponieważ Warszawa i Region Mazowsza, jako obszar badań nad religijnym ruchem turystycznym niepełnosprawnych, którym autorki się zajmowały w ramach projektów badawczych ds.-144 oraz ds.-245, nie został dotychczas objęty uwagą innych badaczy, autorki mają nadzieję, że wnioski końcowe z dokonanych badań mogą się okazać pomocne w budowaniu podstaw teoretycznych strategicznych planów zrównoważonego rozwoju turystyki kulturowo-religijnej na tym obszarze.

\section{Sanktuaria religijne i osoby z niepelnosprawnoscia}

Badania terenowe przeprowadzono w latach 2014-2017 w sanktuariach Warszawy i Regionu Mazowsza, które zgodnie z informacją Diecezji Warszawsko-Praskiej mają rangę sanktuarium i nadany akt erygacji.

1. Sanktuaria religijne w granicach administracyjnych Warszawy (stan w roku 2017):

- Sanktuarium Świątynia Opatrzności Bożej (Wilanów, Warszawa)² [330 ooo pielgrzymów w skali roku] $]^{3}$;

2 Stan na rok 2017. Dokumenty erygacji sanktuarium w trakcie przygotowań w czasie trwania badań (nadanie w roku 2016 lipiec - ŚDM), świątynia była odwiedzana przez tysiące pielgrzymów w skali roku i dlatego była już wcześniej, przed nadanym formalnym statusem brana pod uwagę.

$3 \mathrm{~W}$ nawiasie kwadratowym dane szacunkowe za rok 2016, na podstawie deklaracji ustnych przedstawiciela administracji badanych sanktuarium, materiał badań terenowych ds.-245 AWF - wiosna
- Sanktuarium ks. Jerzego Popiełuszki, kościół św. Stanisława Kostki (Żoliborz, Warszawa) [200 ooo pielgrzymów w skali roku];

- Sanktuarium Matki Bożej Nauczycielki Młodych (Siekierki, Warszawa) [10 ooo pielgrzymów w skali roku];

- Sanktuarium Matki Bożej Łaskawej oraz kościół św. Jana (Stare Miasto, Warszawa) [50 ooo pielgrzymów w skali roku] ${ }^{4}$;

- Sanktuarium Matki Zbawiciela (Śródmieście, Warszawa) [120 ooo pielgrzymów w skali roku];

- Sanktuarium Matki Bożej Fatimskiej (Ursus, Warszawa) [5 ooo pielgrzymów w skali roku];

- Sanktuarium w parafii Świętej Trójcy (Solec, Warszawa) [brak danych];

- Sanktuarium św. Andrzeja Boboli Sanktuarium Narodowe (Mokotów, Warszawa) [100 ooo pielgrzymów w skali roku];

- Sanktuarium św. Antoniego (Śródmieście, Warszawa) [3o ooo pielgrzymów w skali roku].

2. Sanktuaria religijne poza granicami administracyjnymi Warszawy (stan w roku 2017):

- Sanktuarium Matki Boskiej Tęskniącej (Powsin k/ Warszawy) [7 ooo pielgrzymów w skali roku];

2017. Należy podkreślić, że był to okres szczególny (w roku 2016: ŚDM, wizyta papieska, 1050 rocznica Chrztu Polski), zatem ilość pielgrzymów w kolejnych latach zapewnie będzie kształtować się inaczej. Tylko dane dla Sanktuarium w Niepokalanowie oraz Sanktuarium na Żoliborzu w Warszawie są oficjalnie potwierdzone przez Instytut Statystyki Kościoła Katolickiego Pallotynów (dostęp: czerwiec 2017).

4 Sanktuarium Matki Bożej Łaskawej oraz kościół św. Jana (Stare Miasto, Warszawa) były badane jednocześnie (sanktuarium jest tylko w Kościele Jezuickim, a nie w Katedrze) ponieważ są położone w bezpośrednim sąsiedztwie, najczęściej odwiedzane łącznie przez grupy turystów - pielgrzymów odwiedzających Stare Miasto w Warszawie 
- Sanktuarium Matki Bożej Lewczyńskiej Pocieszycielki Strapionych (Lewiczyn k/ Grójca) [2 ooo pielgrzymów w skali roku];

- Sanktuarium Matki Bożej Radosnej Opiekunki Przyrody (Secymin-Nowiny) [brak danych];

- Sanktuarium Parafii Miłosierdzia Bożego (Ożarów Mazowiecki) [brak danych];

- Sanktuarium Prymasowej Wspomożycieli (Rokitno k/ Błonia) [brak danych];

- Sanktuarium NMP w Niepokalanowie (Niepokalanów k/ Sochaczewa) [80o ooo pielgrzymów w skali roku] $]^{5}$. Wymienione sanktuaria były i są otwarte dla turystów, co było koniecznym warunkiem dla przeprowadzenia badań (Mikos von Rohrsheidt 2011: 35-58). Należy zaznaczyć, że z uwagi na bezpieczeństwo świątyni i wiernych, są one otwierane coraz częściej w określone dni i godziny (informacja na stronie internetowej oraz przy wejściu głównym). Do rzadkości należy sanktuarium otwarte przez cały dzień; do takich wyjątków należy Niepokalanów odwiedzany przez 800 ooo pielgrzymów i wiernych w skali roku.

Podjęcie tego tematu wydawało się ważne ze względu na masowość ruchu turystycznego obserwowanego w miejscach kultu religijnego. Z przeprowadzonych przez innych autorów badań wynika, że sanktuaria religijne, przyciągają turystów, nie tylko nastawionych na duchowe przeżycia, także nastawionych na turystykę krajoznawczą. $\mathrm{Na}$ podstawie materiału zebranego w czasie naszych badań, wywiadów przeprowadzonych wśród odwiedzających sanktuaria w Warszawie i Regionie Mazowsza, możemy wyróżnić trzy grupy turystów:

- osoby, dla których podstawowym celem jest modlitwa, kontemplacja, uczestnictwo w ceremoniach religij-

5 Dane statystyczne potwierdzone przez Instytut Statystyki Kościoła Katolickiego Pallotynów (dostęp: czerwiec 2017) nych, uroczystościach kościelnych (pielgrzymi, przeważnie uczestniczący w wyjazdach zorganizowanych);

- osoby, dla których równie ważnym celem, obok przeżyć religijnych, jest motyw krajoznawczy, poznanie historii, architektury sanktuariów (turystyka kulturalno-religijna, poznawcza), poznanie zabytków leżących w okolicy sanktuarium, odwiedziny u krewnych lub lekarza-specjalisty, zakupy;

- $\quad$ osoby, które odwiedzają sanktuaria religijne (w tym obcych dla siebie wyznań, z którymi się nie identyfikują) wyłącznie w celu poznania kultury, bez nastawienia religijnego (turystyka kulturowa).

Z materiału badań ds.-245 wynika, że w Warszawie i Regionie Mazowsza dominują przedstawiciele drugiej grupy, dla których motyw religijny jest równie ważny jak krajoznawczy lub inne motywacje (odwiedziny u krewnych, zwiedzanie miasta i regionu).

Ta tendencja jest zauważona również przez wielu innych badaczy, także opisana w literaturze zagranicznej jako charakterystyczna dla pielgrzymek w Europie (Blackwell 2001: 35-47, Dallen 2009: 11-17, Gonia et al. 2012: 149-161, Jackowski 2010: 17-31, Kazimierczak 2012: 5-21, Kowalski et al. 2011: 71-84, Nolam 1992: 68-78, Panasiuk 2011: 361-373, Rotherham 2009: 64-77, Różycki 2012: 161-179, Rinchede 1992: 51-67, Swatos et al. 2002: 49-51), potwierdzająca także wcześniejsze badania autorów (Pawlikowska-Piechotka 2006: 59-68, 2007: 213227, 2016: 241-256).

Z przeprowadzonych badań terenowych w Warszawie i Regionie Mazowsza (20142017) wynika, że około 14\% odwiedzających to osoby z niepełnosprawnością (najczęściej deklarowane są problemy motoryczne, wady wzroku i słuchu), około $45 \%$ to osoby powyżej 60 roku życia, $5 \%$ rodziny z małymi dziećmi w wózkach. Pomimo takiej sylwetki odwiedzających (blisko 65\% wymaga wprowadzania ułatwień), nie wszystkie obiekty sakralne i ich otoczenie są w pełni dostępne, z uwagi na występowanie barier 
architektonicznych i urbanistycznych. Badane sanktuaria okazały się być przygotowane dla turystów niepełnosprawnych niejednakowo, w bardzo różnym stopniu.

Różnice dostępności dla niepełnosprawnych są widoczne przede wszystkim w odniesieniu do budynków zabytkowych (Sanktuarium Matki Bożej Łaskawej na Starym Mieście, Sanktuarium Matki Bożej Zbawiciela, sanktuaria w Lewiczynie, w Rokitnie) oraz wznoszonych współcześnie. W obiektach niedawno wybudowanych (po wejściu w życie ustawy w roku 2002 o konieczności dostosowania budynków użyteczności publicznej i ich otoczenia dla osób niepełnosprawnych), bariery w dostępności są eliminowane (Ursus - Niedźwiadek, Sanktuarium na Siekierkach, Świątynia Opatrzności Bożej na Wilanowie). Natomiast historyczne sanktuaria są na ogół słabiej przygotowane dla osób z różnego rodzaju niepełnosprawnością, duże trudności osoba na wózku może mieć już z dostaniem się do wnętrza świątyni, do nawy głównej i kaplic bocznych. Administracje świątyń starają się temu zaradzić na przykład przez instalowanie przy wejściu głównym ramp stałych (Kościół św. Stanisława Kostki w Warszawie, Rokitno pod Pruszkowem) lub przenośnych (Sanktuarium Matki Bożej Zbawiciela w Warszawie).

Wśród budynków starszych, o randze zabytku zwraca uwagę przygotowanie dla niepełnosprawnych pielgrzymów kościoła św. Stanisława Kostki na Stary Żoliborzu, wzniesionego w latach 30-tych XX wieku. Specjalnie wyznaczona trasa ułatwia osobie na wózku orientację w terenie, możliwość wejścia do wnętrza sanktuarium przy pomocy zewnętrznej rampy (od strony wschodniej), bezpieczne poruszanie w otoczeniu sanktuarium. Niestety wciąż niedostępne są muzeum i kaplica w podziemiach oraz Dom Pielgrzyma, ale wprowadzanie kolejnych udogodnień jest $\mathrm{w}$ planach parafii. Na tle badanych zabytkowych miejsc kultu wyjątkowo wzorowo dla niepełnosprawnych pielgrzymów jest przygotowane sanktuarium w Niepokalanowie. Dostępna dla odwiedzających jest bazylika, dzięki wygodnej rampie przy wejściu głównym, muzeum, toalety, usługi gastronomii. Nie mają też problemów z dostępnością wierni do barokowych kościołów na Solcu i w Powsinie, $\mathrm{z}$ uwagi na znaczne podniesienie się warstw drogowych i zniwelowanie różnic poziomów.

$\mathrm{Z}$ materiału badań wynika, że niezwykle rzadko odwiedzający z niepełnosprawnością narzekają na komfort poruszania się we wnętrzu sanktuarium, przejścia w nawie głównej są szerokie i równe, do kaplic bocznych (jeżeli są na innym poziomie) można wjechać po pochylniach (kościół św. Stanisława Kostki).

Przy tych świątyniach, przy których znajdują się parkingi, miejsca dedykowane niepełnosprawnym (dobrze oznakowane i o właściwych parametrach szerokości stanowiska) są na ogół wygodnie zlokalizowane, znajdując się blisko wejścia na teren sanktuarium. Niemniej pielgrzymi z niepełnosprawnością odwiedzający Warszawę zwracali uwagę na problem na trudności w dotarciu do sanktuarium, zbyt małą ilość miejsc parkingowych 'z kopertką' blisko wejścia do sanktuarium w świątyniach położonych na Starym Mieście, Powiślu oraz w Śródmieściu (Sanktuarium Matki Bożej Zbawiciela).

Niestety wciąż do rzadkości należy informacja na temat sanktuarium przygotowana z myślą o osobach niepełnosprawnych (użytkownikach wózków, niedowidzących). Dedykowanych informacji na temat sanktuariów i warunków ich odwiedzania często nie można wyszukać ani na stronach internetowych, (jako informacji pre-visit), ani na miejscu, (jako informacji in situ). Te braki sa problemem istotnym, $\mathrm{z}$ uwagi na demograficzny przekrój uczestników turystyki religijnej, duży w niej udział osób starszych i mogących mieć problemy motoryczne lub niedowidzących. Autorki pragną zaznaczyć, że na taką strukturę wiekową pielgrzymów i wiernych wskazują także inni badacze (Buczkowska 2012: 53-75, Dziubiński et al. 2012: 37-54, Jackowski 2010: 17-31). Należy podkreślić, że zapewnienie 
wiarygodnej informacji (internetowej i na miejscu w świątyni) nie jest już ograniczone rekomendacjami konserwatorskimi czy przestrzennymi i ten brak to wyłącznie zaniechanie administracji sanktuarium.

Innym trudnym do rozwiązania problemem jest tolerowanie w miejscach publicznych, w tym w świątyniach, obecności psa - przewodnika. Zgodnie z prawem - osoby niewidome w towarzystwie psa - przewodnika mają prawo wejścia i przebywania w placówkach handlowych, kulturalnych, oświatowych, obiektach sportowych, bankach i urzędach. Chociażby z doświadczeń codziennych lub doniesień mediów wiemy, że przepis ten jest bardzo często kwestionowany, a w odniesieniu do miejsca kultu - jest to zagadnienie wciąż drażliwe, które pozostaje bez jednoznacznego rozwiązania.

Ponadto, (pomimo stałej poprawy), obserwujemy wciąż niedostosowanie otoczenia świątyń: ulic miejskich, środków komunikacji, lokali gastronomicznych, placówek muzealnych do potrzeb osób starszych i niepełnosprawnych. Tym samym turyści - pielgrzymi mają także problemy z dostępnością do podstawowej infrastruktury turystycznej (hoteli, lokali gastronomicznych, usług handlu, muzeów). Obecnie tylko nieliczne usługi hotelarskie i gastronomiczne mogą być dla nich dostępne, i to usługi noclegowe, - co należy podkreślić - nie najtańsze (w tym domy pielgrzyma i domy rekolekcyjne przy sanktuariach). A przecież uczestnicy pielgrzymek, jak podkreślają liczni badacze problemu, to bardzo często osoby starsze, przedstawiciele najmniej zamożnej grupy społecznej (Dziubiński et al. 2012: $37-$ 54, Jackowski 2010: 17-31).

Zgodnie z najnowszymi danymi GUS w Warszawie liczba niepełnosprawnych wynosi ponad 200 ooo osób (GUS 2016: 43-51). Ponieważ łącznie z osobami w wieku 6o+ grupa ta liczy już ponad 350 ooo mieszkańców, oznacza to, że badany przez nas problem dostępności miejsc kultu nie tylko dotyczy niepełnosprawnych pielgrzymów, ale także licznych wiernych rekrutujących się spośród członków społeczności lokalnych. Co więcej ta ilość, zgodnie z prognozami demografów, będzie stale rosła w kolejnych dekadach, wraz z wydłużającym się wiekiem. Jednak ze względu na wciąż występujące w naszym środowisku zamieszkania istotne bariery urbanistyczne i architektoniczne, ta grupa społeczna wciąż w niewielkim stopniu uczestniczy w życiu społecznym, w tym w turystyce religijnej. A liczne badania (wspomniane wcześniej) wskazują, że jest to grupa społeczna szczególnie taką formą turystyki zainteresowana [Fig. 2,3].

W Polsce, zabiegi planistyczne związane ze znoszeniem barier dostępności są regulowane przepisami prawa, wchodzą w zakres planowania zintegrowanego, mającego na celu uwzględnienie potrzeb różnych grup społecznych. Muszą jednak uwzględniać zapisy rekomendacji konserwatorskich dotyczących ochrony walorów przyrodniczych i dóbr kultury, co niejednokrotnie przekreśla możliwości adaptacji obiektu sakralnego dla potrzeb niepełnosprawnych. Przykładem, że dobra wola i starania dają pożądany efekt jest przygotowanie dla niepełnosprawnych odwiedzających sanktuarium w Niepokalanowie, którego większość obiektów jest dla osób niepełnosprawnych w pełni dostępna.

Nadzieją na polepszenie dostępności miejsc kultu religijnego dla osób z różnego rodzaju niepełnosprawnością są plany wprowadzania kolejnych udogodnień (administracje wszystkich bez wyjątku badanych obiektów taką deklarację składały) oraz działania władz samorządowych. Tylko w roku 2017 mają być wprowadzone ulepszenia i zniesione bariery dostępności w 200 miejscach przestrzeni publicznej Warszawy, takie same propozycje w mniejszej skali mają poszczególne władze samorządowe w miejscowościach odwiedzanych przez pielgrzymów. Narzędziem pomocnym dla tych działań, jak mamy nadzieję, może się okazać proponowana przez nas Karta Sanktuarium Dostępnego (KSD). 


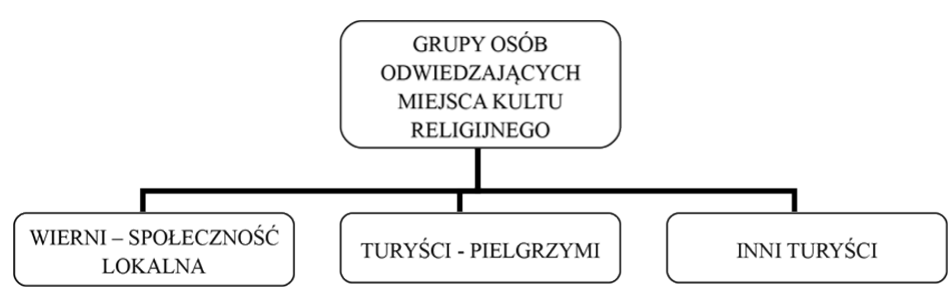

Fig. 2. Charakterystyczne trzy grupy osób odwiedzających miejsca kultu religijnego

Źródło: Opracowanie autorów na podstawie badań terenowych 2014 - 2017 (ds.-144 oraz ds. 245 Akademia Wychowania Fizycznego Józefa Piłsudskiego w Warszawie, granty Ministerstwa Nauki i Szkolnictwa Wyższego)

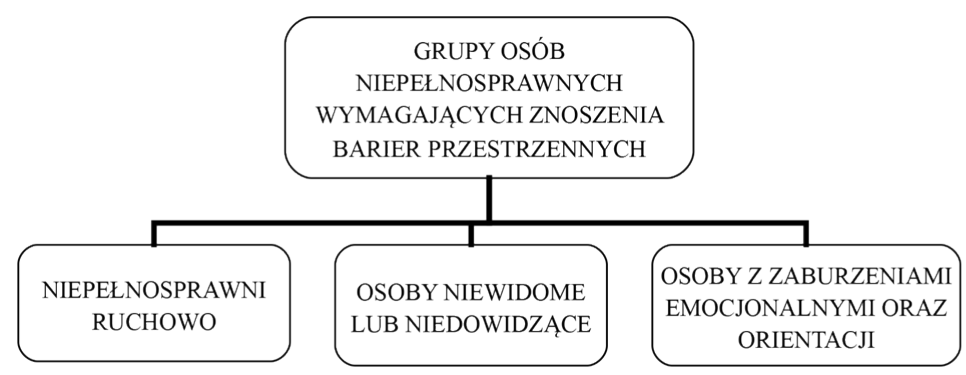

Fig. 3 Podstawowe grupy turystów niepełnosprawnych, w szczególności wymagające znoszenia barier architektonicznych i urbanistycznych oraz nie - materialnych (takich jak na przykład informacja pre-visit, informacja in situ)

Źródło: Opracowanie autorów na podstawie badań terenowych 2014 - 2017 (ds.-144 oraz ds. 245 Akademia Wychowania Fizycznego Józefa Piłsudskiego w Warszawie, granty Ministerstwa Nauki i Szkolnictwa Wyższego)

\section{Karta sanktuarium dostępnego (KSD)}

Metoda oceny dostępności sanktuariów i ich otoczenia dla osób niepełnosprawnych - to zadanie złożone, wielowątkowe. Pod uwagę należy brać kryteria dostępności związane zarówno z barierami materialnymi (architektoniczne, urbanistyczne) jak i nie - materialnymi (jakimi są usługi informacji pre-visit oraz in situ). Ponadto przy identyfikacji utrudnień dostępności należy uwzględnić osoby z różnym rodzajem niepełnosprawności, osoby starsze i rodziny z małymi dziećmi (w wieku o - 4).

Prezentowana $\mathrm{w}$ tym rozdziale metoda pomocna przy identyfikacji utrudnień dostępności miejsc kultu religijnego dla osób z niepełnosprawnością, powstała na podstawie analizy materiału zgromadzonego w czasie badań terenowych, case studies przeprowadzonych w 15 wybranych sanktuariach Warszawy (9 obiektów) i Regionu Mazowsza (6 obiektów) oraz studiów literatury przedmiotu, prac teoretycznych poświęconych temu zagadnieniu (prace te były prowadzone w ramach projektów badawczych ds.-144 oraz ds.-245 AWF Warszawa).

Dla większej przejrzystości i praktyczności, autorki zdecydowały się ująć opracowaną metodę ('Kartę Sanktuarium Dostępnego' KSD) w postaci trzech tabel ewaluacyjnych (TEA, TEB oraz TEC), pomocnych dla obiektywnego wyróżnienia występujących utrudnień w przestrzeni sanktuarium. Metodę pilotażowo testowano we wszystkich 15 wybranych do badań sanktuariach, $\mathrm{w}$ takim zakresie $\mathrm{w}$ jakim to było możliwe (przede wszystkim na podstawie warunków stawianych ze strony administracji obiektu 
oraz zakresu informacji możliwych do zgromadzenia z innych zródeł). Jak się wydaje, dodatkowym atutem metody jest pomoc w uporządkowaniu grup utrudnień, co ułatwia w kolejnych etapach plany dla ich znoszenia, zatem może być praktyczną pomocą dla administratorów obiektów i projektantów modernizacji sanktuariów.

Tabele ewaluacyjne TEA, TEB oraz TEC tworzące 'Kartę Sanktuarium Dostępnego', są przygotowane dla oceny trzech wyróżnionych segmentów: przestrzeni sanktuarium i jego otoczenie, miejsca zakwaterowania pielgrzymów (jakimi mogą być tak różnorodne obiekty jak domy rekolekcyjne, domy pielgrzyma, klasztory, hotele, pensjonaty lub kwatery prywatne) oraz informacja dla pielgrzymów pre-visit oraz in situ. Kryteria dostępności sanktuarium w opracowanej metodzie zostały uwzględnione $\mathrm{z}$ punktu widzenia podstawowych warunków przestrzennych i ułatwień dla mobilności osób z różnego rodzaju niepełnosprawnością (zestawienie syntetyczne przyjętych kryteriów w tabelach na końcu podrozdziału). Metoda identyfikacji utrudnień dostępności sanktuariów i ich otoczenia w postaci 'Karty Sanktuarium Dostępnego’ KSD, uwzględnia zarówno standardy budowlane i regulacje prawne obowiązujące w Polsce jak i aktualne rekomendacje i zalecenia EU w tym zakresie (stan na rok 2017). Należy podkreślić, że prezentowaną metodę można stosować tylko w czasie wizji lokalnej, bezpośrednio na miejscu w obiekcie. Odzwierciedla stan faktyczny w momencie oceny dostępności obiektu i jego otoczenia (wypełniania trzech tabel ewaluacyjnych TEA, TEB, TEC - składających się na 'Kartę Dostępności Sanktuarium' KSD) dla osób z różnego rodzaju niepełnosprawnością, osób starszych oraz rodzin z małymi dziećmi (w wieku o-4).

Prezentowana metoda wyróżnia tylko kryteria ogólne. Ponieważ system zakłada elastyczność i otwartość stosowania, jest możliwe rozbudowanie 'Karty Sanktuarium Dostępnego, jej tablic ewaluacyjnych o kolejne, bardziej szczegółowe kryteria $\mathrm{w}$ miarę potrzeb, odpowiednio w danym segmencie problemowym (na przykład bardzo dokładna ocena spełnienia standardów wymaganych w odniesieniu do toalet dedykowanych dla niepełnosprawnych). $\mathrm{Z}$ tego też względu w końcowej części tablic ewaluacyjnych (TEA, TEB oraz TEC) jest zostawione miejsce na uwagi i komentarze osoby dokonującej oceny dostępności obiektu i jego otoczenia w czasie wizji lokalnej, na miejscu w sanktuarium.

Odradza się wprowadzenie pomiarów na podstawie planów architektoniczno-budowlanych badanego miejsca kultu religijnego, ponieważ w trakcie realizacji inwestycji (remontów) mogą ulec zmianie. Kilkucentymetrowe odchylenia nie są na ogół nanoszone na plany (jako korekta) w czasie odbioru budynku przez inspekcję budowlaną, a mogą w znaczącym stopniu utrudnić (lub przeciwnie - umożliwić) swobodne i bezpieczne manewry wózkiem. Dla stosowania metody nie są konieczne ani specjalistyczne przygotowanie, ani narzędzia (poza zwykłą, powszechnie $\mathrm{w}$ handlu dostępną sztywną 'miarką' ciesielską o standardowej długości $200 \mathrm{~cm}$ lub $300 \mathrm{~cm}$ ). Należy też zaznaczyć, że coraz bardziej popularne są obecnie instrumenty dla elektronicznych pomiarów, stosowane do inwentaryzacji architektoniczno-budowlanych), ale ich prawidłowe użycie wymaga wiedzy i praktyki. Zalecane jest stosowanie metody i wypełnianie tabel ewaluacyjnych TEA, TEB oraz TEC przez dwie osoby, dla ułatwienia nanoszenia notatek i wykonywania jednocześnie pomiarów, takich jak szerokości prześwitów drzwi, szerokość korytarzy czy pola manewrowego dla wózka w toalecie itp. [Tabela 1]. Czas, jaki należy poświęcić na ocenę dostępności budynku i jego otoczenia dla osób z niepełnosprawnością posługując się opisaną metodą 'Karty Sanktuarium Dostępnego', jest trudny do określenia z góry. Zależeć będzie od wielkości obiektu (zespołu obiektów) oraz stopnia szczegółowości oceny jakiej chcemy dokonać, zatem jest trudny do oszacowania z góry. Bez wątpienia jednak należy się liczyć przy większych i złożonych funkcjonalnie obiektach (Niepokalanów, Jasna Góra) 


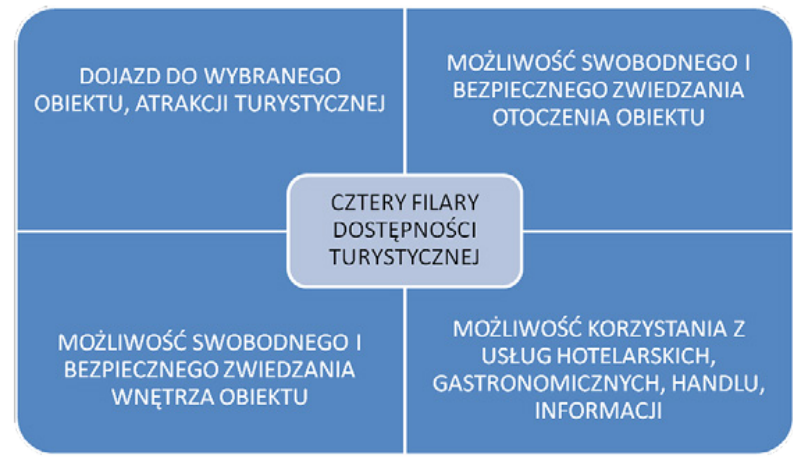

Fig. 4. Filary dostępności turystycznej atrakcji turystycznych dla osób z niepełnosprawnością zgodnie z rezolucją UN WTO „Creating Tourism Opportunities for Handicapped People” A/RES/284/(IX) z 1991 roku

Źródło: Opracowanie autorów na podstawie badań terenowych 2014 - 2017 (ds.-144 oraz ds. 245 AWF w Warszawie, grant MNiSW)

z wielodniowymi pracami nawet kilkuosobowego zespołu.

Prezentowana metoda zostanie przetestowana w pełnym zakresie w dwóch sanktuariach na terenie Warszawy (Sanktuarium Matki Bożej Zbawiciela oraz Kościół św. Stanisława Kostki) w roku 2018. Po analizie wyników z tego etapu badań, zostaną naniesione na arkusze ewaluacyjne TEA, TEB oraz TEC kolejne korekty.

\section{Podsumowanie i dyskusja}

W podjętych przez autorki badaniach, intencją było rozeznanie uwarunkowań kulturowych, przestrzennych i społecznych zrównoważonego rozwoju turystyki kulturowo-religijnej na terenie wybranych sanktuariów - mierzonych przede wszystkim ich dostępnością. Jak mają nadzieję, uogólnione wnioski z tych badań, a w szczególności opracowana metoda oceny dostępności miejsc kultu dla niepełnosprawnych KSD (za pomocą ujednoliconych i uporządkowanych kryteriów), pozwoli na szersze ich wykorzystani niż tylko badanego regionu. Ponadto, dostępność sanktuariów, jest co prawda problemem zaledwie wycinka przestrzeni turystycznej, ale pewne zasady zwiększania ich dostępności mogą mieć zastosowanie powszechniejsze, w odniesieni do obiektów użyteczności publicznej także o innych funkcjach.

W badaniach przyjęto założenie, że zawartość tematyczna zgromadzonego materiału badań terenowych i studia literatury pozwolą na identyfikację najistotniejszych czynników składających się na uwarunkowania przestrzenne i społeczne zrównoważonego rozwoju turystyki w danym sanktuarium. Natomiast uogólnione wnioski pozwolą na zbudowanie podstaw teoretycznych kształtowania kierunków polityki regionalnej w tym zakresie, przede wszystkim uzyskanie w efekcie aplikacyjnym metody pomocnej przy diagnozowaniu stopnia dostępności miejsc kultu dla osób z niepełnosprawnością (opracowanej w postaci Karty Dostępności Sanktuarium - KDS) [Fig. 4, 5, $6,7]$.

Należy podkreślić, że z pewnością zabiegi znoszenia barier będą bardziej skuteczne, jeżeli będzie zapewniony współudział, na wszystkich etapach realizacji planu, wszystkich zainteresowanych takimi projektami: władz samorządu terytorialnego, instytucji rządowych, przedstawicieli społeczności lokalnej oraz organizacji pozarządowych (w tym organizacji reprezentujących interesy osób niepełnosprawnych). Ich głos w warunkach demokratycznego państwa przy podejmowania decyzji ważnych dla 


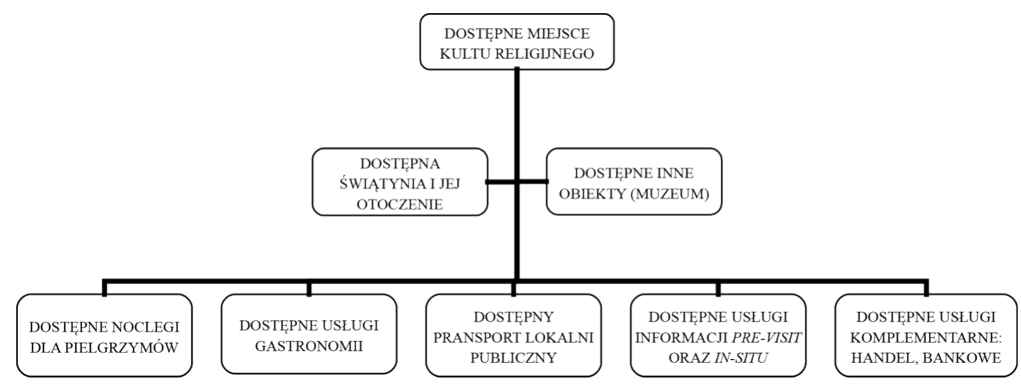

Fig. 5. Dostępne miejsce kultu religijnego, bez barier dla osób z różnego rodzaju niepełnosprawnością - uwarunkowania segmentów przestrzennnych oraz typowo turystycznych usług oraz infrastruktury (podstawowych i komplementarnych) - zgodnie z rezolucją UN WTO (1991 rok)

Źródło: Opracowanie autorów na podstawie badań terenowych 2014-2017 (ds.-144 oraz ds. 245 Akademia Wychowania Fizycznego Józefa Piłsudskiego w Warszawie, granty Ministerstwa Nauki i Szkolnictwa Wyższego)

\begin{tabular}{|c|c|}
\hline ETAI & $\begin{array}{l}\text { - Zebranie materiału źródłowego na temat uwarunkowań dostępności przestrzeni } \\
\text { publicznej dla osób z różnego rodzaju niepełnosprawnością. } \\
\text { - Badania terenowe w } 15 \text { wybranych sanktuariach Warszawy ( } 9 \text { obiektów) oraz Mazowsza } \\
\text { ( } 6 \text { obiektów). }\end{array}$ \\
\hline ETA & $\begin{array}{l}\text { - Opracowanie metody identyfikacji utrudnień w dostępności sanktuarium i ich otoczenia } \\
\text { 'Karta Sanktuarium Dostepnego' w formie trzech tablic ewaluacyjnych TEA, TEB, TEC. } \\
\text { - Opracowanie zasad stosowania 'Karty Sanktuarium Dostępnego' (KSD) - wypełniania } \\
\text { tablic ewaluacyjnych TEA, TEB, TEC. }\end{array}$ \\
\hline EFE & $\begin{array}{l}\text { - Testowanie metody w wybranych do badań sanktuariach (tych samych co w poprzednich } \\
\text { etapach: Warszawy i regionu Mazowsza. } \\
\text { - Na podstawie identyfikacji utrudnień opracowanie rekomendacji dla ich znoszenia w } \\
\text { miesiąca kultu religijnego (wnioski indywidualne dla każdego z badanych sanktuariów } \\
\text { oraz uogólnione). }\end{array}$ \\
\hline
\end{tabular}

Fig. 6. Etapy opracowania metody identyfikacji utrudnień w dostępności miejsc kultu religijnego dla osób z niepełnosprawnością za pomocą tablic TEA, TEB, TEC (tworzących 'Kartę Sanktuarium Dostępnego')

Źródło: opracowanie autorów na podstawie badań terenowych 2014 - 2017 (ds.-144 oraz ds. 245 Akademia Wychowania Fizycznego Józefa Piłsudskiego w Warszawie, granty Ministerstwa Nauki i Szkolnictwa Wyższego)

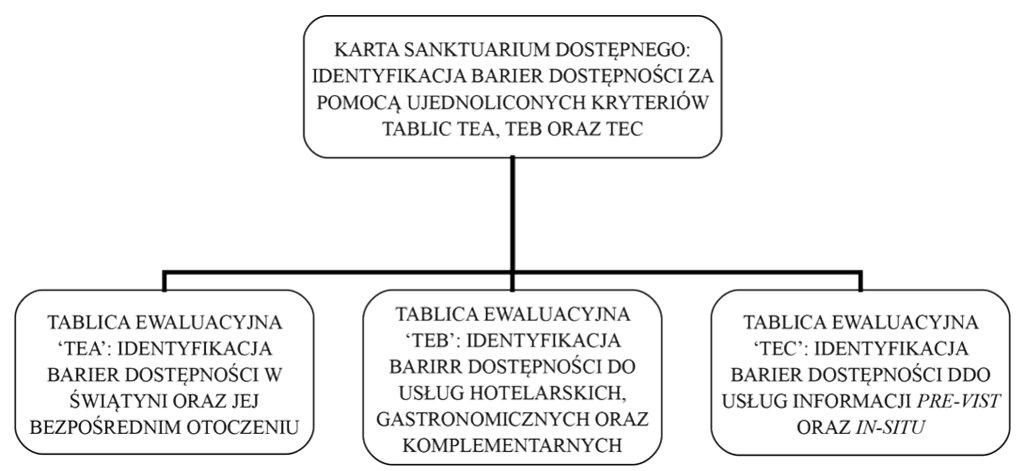

Fig. 7. Metoda identyfikacji utrudnień w dostępności miejsc kultu religijnego dla osób z niepełnosprawnością za pomocą ujednoliconych kryteriów trzech tablic ewaluacyjnych: TEA, TEB, TEC (razem tworzących 'Kartę Sanktuarium Dostępnego')

Źródło: Opracowanie autorów na podstawie badań terenowych 2014 - 2017 (ds.-144 oraz ds. 245 Akademia Wychowania Fizycznego Józefa Piłsudskiego w Warszawie, granty Ministerstwa Nauki i Szkolnictwa Wyższego) 
Tabela 1. Podstawowe parametry przestrzenne, które powinny być uwzględniane dla ułatwienia podstawowych czynności osób niepełnosprawnych (obiekty użyteczności publicznej, sanktuaria $\mathrm{i}$ ich otoczenie - w tym pomieszczenia hotelarskie w domach rekolekcyjnych, domach pielgrzyma, kwaterach prywatnych), ujednolicone kryteria przyjęte w tablicach ewaluacyjnych TEA, TEB oraz TEC (składowych Karty Sanktuarium Dostępnego - KSD)

Lp. Wymiary i gabaryty pomieszczeń w miejscach kultu religijnego i ich otoczeniu powinny być uwzględniane dla wiernych i turystów - pielgrzymów odwiedzających sanktuarium, uwzględniające w szczególności:

\begin{tabular}{ll}
\hline 1. Użytkownika wózka: wymiar czołowy, wymiar boczny \\
2. Użytkownika wózka: powierzchnia manewrowa wózka, powierzchnia dla transferu \\
3. Użytkownika wózka: wraz z osobą towarzyszącą: wymiar czołowy, wymiar boczny \\
4. Użytkownika wózka: przy umywalce \\
5. Użytkownika wózka: korzystający z WC (powierzchnia transferu) \\
6. Użytkownika wózka: korzystający z natrysku \\
7. Użytkownik wózka: korzystający z wanny \\
8. Użytkownika wózka: w drzwiach, na korytarzu \\
9. Użytkownika wózka: przy stole \\
10. Osoby chodzącej o kulach: wymiar czołowy, wymiar boczny \\
11. Osoby chodzącej o kulach: w drzwiach, na korytarzu \\
12. Osoby chodzącej z laską (niewidomy): wymiar czołowy, wymiar boczny \\
13. Osoby chodzącej z laską (niewidomy): w drzwiach, na korytarzu \\
14. $\quad$ Osoby z ograniczoną sprawnością chodzenia po schodach \\
15. Osoby z wózkiem dziecięcym
\end{tabular}

Źródło: Opracowanie autorów na podstawie badań terenowych 2014 - 2018 (ds.-144. oraz ds. 245 Akademia Wychowania Fizycznego Józefa Piłsudskiego w Warszawie, granty Ministerstwa Nauki i Szkolnictwa Wyższego).

całej społeczności terytorialnej, jest zawsze niezmiernie istotny. Dobrym przykładem takiego programu rozwiązań kompleksowych jest dokument Kierunki rozwoju turystyki dla województwa małopolskiego na lata 2008-2013 - (Priorytet: turystyka religijna), opracowany przez Urząd Marszałkowski Województwa Małopolskiego w roku 2000. Pozostaje mieć nadzieję, że i Warszawa wraz z Regionem Mazowsza takiego programu się doczeka. Na razie mamy do czynienia tylko z projektami wyrywkowymi, choć z pewnością bardzo cennymi, w rodzaju Szlaki architektury sakralnej Mazowsza czy Drewniane skarby Mazowsza, przygotowanymi przez Centrum Duszpasterstwa
Archidiecezji Warszawskiej, co należy podkreślić, także pod kątem potrzeb turystów niepełnosprawnych.

Z przeprowadzonych badań wynika, że bez wątpienia, pomimo stałej obserwowanej poprawy dostępności przestrzeni publicznej dla osób niepełnosprawnych konieczne są wciąż zabiegi, ułatwiające codzienne życie i podróż niepełnosprawnym pielgrzymom. Zakładając, zgodnie z prognozami demograficznymi i badaniami GUS, że grupa osób niepełnosprawnych w naszym społeczeństwie będzie stale rosła, przygotowanie przestrzeni recepcyjnej bez barier dostępności dla tej grupy turystów jest juz bardzo pilnym i ważnym zadaniem. Przestrzeń turystyki bez barier pozwoli osobom niepełnosprawnym pełniej 
uczestniczyć w codziennym życiu społecznym, pozwalając na większą samodzielność, dając szansę na szeroko rozumianą rehabilitację (społeczną, zawodową), zarówno na rozrywkę, jak i na dobrze przygotowane miejsce pracy - w rezultacie dając satysfakcję i podnosząc jakość ich życia.

Na zakończenie autorki pragną zastrzec, że chociaż ich intencją jest, aby efekty aplikacyjne pracy miały charakter uniwersalny i ponadczasowy, to zawarte tu wnioski i rozwiązania powinny być stale weryfikowane i zastępowane wynikami z najnowszych badań, dostosowane do aktualnych aktów prawnych. Na przykład wraz z postępem technologii i produkcji coraz doskonalszych bioprotez czy innowacyjnych konstrukcji wózków inwalidzkich (wprowadzających takie zmiany jak redukcja promienia skrętu, poprawa stabilności), część przyjętych dla zaproponowanej 'Karty Sanktuarium Dostępnego' wskaźników będzie musiała z czasem ulec korekcie.

\section{Bibliografia}

Blackwell R. (2001): Motivations for Religious Tourism, Pilgrimage, Festivals and Events [w]: 'Religious Tourism and Pilgrimage Festivals Management', CABI Publishing, $35-47$.

Buczkowska K. (2012): Aspekty religijne w podróżach kulturowych osób starszych [w]: 'Folia Turistica' [red. Różycki P.], 27/ 2012, Akademia Wychowania Fizycznego im. Bronisława Czecha w Krakowie, Kraków, 53-75.

Dallen J.T., Olsen D.H. (2009): Tourism, Religion and Spiritual Journeys, Routledge, NewYork.

Dziubiński Z., Jasny M. (2012): Socjologiczna charakterystyka uczestników Warszawskiej Archidiecezjalnej Pielgrzymki Metropolitarnej na Jasna Górę [w]: 'Folia Turistica' [red. Różycki P.] 27/2012, Akademia Wychowania Fizycznego im. Bronisława Czecha w Krakowie, Kraków, 37-53.

Gonia A., Kozłowska-Adamczak M., Michniewicz-Ankiersztajn H. (2012): Obiekty sakralne XIX iXX wieku, jako produkt turystyki kulturowej i religijnej - przyktad Bydgoszczy [w]: 'Folia Turistica' [red. Różycki P.] 27/2012, Akademia Wychowania Fizycznego im. Bronisława Czecha w Krakowie, Kraków, 149-161.
Grabowski J., Milewska M., Stasiak A. (2007): Vademecum organizatora turystyki niepetnosprawnych, Wyższa Szkoła Turystyki i Hotelarstwa, Łódz. Główny Urząd Statystyczny (2016): Zdrowie i ochrona zdrowia 2015, GUS Warszawa.

Inskeep E. (2001): Tourism Planning: An Integrated and Sustainable Development Approach, Willey Publishing, London.

Jackowski A. (2010): Pielgrzymki a turystyka religijna [w]: Turystyka religijna, Uniwersytet Szczeciński, Szczecin, 17-31.

Kapera I. (2011): Samorzad terytorialny a rozwój turystyki religijnej i pielgrzymkowej $w$ Krakowie [w]: 'Turystyka religijna - zagadnienia interdyscyplinarne' [red. Panasiuk A.], Uniwersytet Szczeciński, Szczecin, 271-282.

Kazimierczak M. (2012): Duchowy wymiar podróżowania [w]: 'Folia Turistica' [red. Różycki P.] 27/2012, Akademia Wychowania Fizycznego im. Bronisława Czecha w Krakowie, Kraków, 5-21.

Kowalski T., Ruszkowski M. J. (2011): Miejsca kultu religijnego jako czynnik atrakcyjności regionu [w]: 'Turystyka religijna - zagadnienia interdyscyplinarne' [red. Panasiuk A.], Uniwersytet Szczeciński, Szczecin, $71-84$.

Kuryłowicz E. (2005): Projektowanie uniwersalne. Udostępnienie otoczenia niepetnosprawnym, CEBRON, Fundacja Integracja, Warszawa.

Łobożewicz T. (20oo): Turystyka i rekreacja osób niepetnosprawnych, Wyższa Szkoła Ekonomiczna w Warszawie, Warszawa

Mikos von Rohrsheidt A. (2011): Faktyczna dostępność obiektów sakralnych, jako problem turystyki religijnej $w$ Polsce $[\mathrm{w}]$ : 'Turystyka religijna - zagadnienia interdyscyplinarne' [red. Panasiuk A.], Uniwersytet Szczeciński, Szczecin, 35-58.

Nolam M. L. (1992): Religious sites as tourism attractions in Europe [w]: 'Annals of Tourism Research', 19(1)/1992, ELSEVIER, 68-78.

Panasiuk A. (2011): Dylematy promocji produktu turystyki religijnej [w]: 'Turystyka religijna - zagadnienia interdyscyplinarne' [red. Panasiuk A.], Uniwersytet Szczeciński, ZN 647, Szczecin, 361-373.

Pawlikowska-Piechotka A. (2006): Zrównoważony rozwój miejscowości pielgrzymkowych $[\mathrm{w}]$ : ‘Turystyka i rekreacja - wymiary teoretyczne i praktyczne' [red. Kosiewicz J., Obodyński K.], Uniwersytet Rzeszowski, Rzeszów, 59-68. 
Pawlikowska-Piechotka A. (2007): Nachaltige Raumentwicklung von Wallfahrsorten [w]: 'Nachhaltige Entwicklung In Polen Und Deutschland (Landwirtschaft - Tourismus - Bildung)', [red. Banse G., Kiepas A.], Edition Sigma, Berlin, 213-227.

Pawlikowska-Piechotka A. (2016): Przestrzeń sportu, rekreacji i turystyki bez barier, [seria]: 'Studia i Monografie', Wydawnictwo Naukowe Akademii Wychowania Fizycznego Józefa Piłsudskiego w Warszawie, Warszawa.

Rotherham I. (2009): Sustaining Tourism Infrastructure for Religious Tourists and Pilgrims within the UK $[\mathrm{w}]$ : Religious Tourism and Pilgrimage Festivals Management, CABI Publishing, London, 64-77.

Różycki P. (2012): Kilka uwag o turystyce i pielgrzymowaniu [w]: 'Folia Turistica' [red. Różycki P.] 27/2012, Akademia Wychowania Fizycznego im. Bronisława Czecha w Krakowie, Kraków, 161-179. Rinchede G. (1992): Forms of Religious Tourism [w]: 'Annals of Tourism Research', 19 (1)/ 1992, ELSEVIER, $51-67$.

Skalska T. (2004): Turystyka osób niepetnosprawnych - ograniczenia $i$ możliwości rozwoju, Wyższa Szkoła Hotelarstwa, Gastronomii i Turystyki, Warszawa.
Swatos W.H., Tomasi L. (2002): From Medieval Pilgrimage to Religious Tourism, Chicago Praeger Publishers, Chicago.

Akty prawne

Ustawa z dnia 27 sierpnia 1997 o rehabilitacji zawodowej i społecznej oraz zatrudnieniu osób niepełnosprawnych (Dz.U.1997 nr 123 poz. 776 z dnia 1 września 1997).

Ustawa z dnia 7 lipca 1994 Prawo budowlane (Dz.U.1994 nr 89 poz.414 z dnia 07 lipca 1994).

Rozporządzenie Ministra Infrastruktury z dnia 12 kwietnia 2012 w sprawie warunków technicznych jakim powinny odpowiadać budynki i ich usytuowanie (Dz.U.2002 nr 75 poz.69o z dnia 15 czerwca 2002).

Witryny internetowe

(web-o1) Dane liczbowe na temat ruchu pielgrzymkowego w Polsce, Instytut Statystyki Kościoła Katolickiego Pallotynów; www.opoka.pl, dostęp: marzec 2017.

(web-02) Dane liczbowe na temat ruchu pielgrzymkowego w Polsce (strony 230-249), Główny Urząd Statystyczny GUS, Instytut Statystyki Kościoła Katolickiego SAC: 'Kościół Katolicki w Polsce 1991-2011", Warszawa 2014; www.gus.gov.pl, dostęp: lipiec 2017.

\title{
Sustainable pilgrimage tourism - inclusive religious sanctuaries chart (irsch)
}

\begin{abstract}
Knowing the extent of the detailed conditions for sustainable development of culture - religion tourism seems to be an important issue, because interest in religious tourism, pilgrimages, cultural and religious tourism in Poland seemed to be unabated. Among millions of tourists annually visiting the most popular sanctuaries, many are people with different kind of disabilities, elders and families with toddlers. However the issue was not yet a material for broader and deeper scientific studies in Poland. Weight of the precise of discernment seemed to be particularly important in the context of pilgrims expected in Poland in 2016, on the occasion of World Youth Day, as well as in subsequent years, what will be the likely consequence of this year's celebrations. One of the most important outcomes of the study is the 'Inclusive Religious Sanctuaries Chart' (IRSCH), helpful with identification of the material and non-material barriers. In this text the authors present the findings of research carried out under ds-144 and ds.245 AWF Warsaw projects (Ministry of Science and Higher Education grants for the years 2014-2018).
\end{abstract}

\section{Keywords}

religious tourism, sanctuaries in Warsaw and Mazovia Region, tourism mobility, accessible holy sites 